\title{
Timothy Morton, Humankind: Solidarity with Nonhuman People. London and New York: Verso, 2019, 224 pp., ISBN 9781788731003
}

A Book Review by Xiaoli Yang

"A specter is haunting the specter of communism: the specter of the nonhuman," is the first sentence of Timothy Morton's Humankind: Solidarity with Nonhuman People (2019, p. 1). How do ecological issues relate to Marxism - in particular communism -in the age of the Anthropocene? Humankind stands as Timothy Morton's latest attempt to bridge Marxism, ecocriticism, and object-oriented ontology (O०০). The book teases out the complexities of Marxism and, more specifically, the implied inclusion of the nonhuman in Marx's thought. Morton argues that Marxism can and must include nonhumans (2019, p. 5), and that despite Marxism's anthropocentric focus on human economic relations, it holds promise for positive modes of relations with nonhumans. For Morton, Marxism's anthropocentrism is merely a bug, not a feature (2019, p. 7).

This bug has been hugely exacerbated by the strongly correlationist New Left theory and New Age literature, as well as the long tradition of correlationism from Kant to Hegel to Heidegger in Western philosophy. Correlationism holds that things (correlatees) only exist because of the human (correlator)-be it the Kantian transcendental subject, Hegelian Spirit, or Heideggerian Dasein. For Morton, there is a traumatic fissure that he calls "the Severing" between "reality (the human-correlated world) and the real (ecological symbiosis of human and nonhuman parts of the biosphere" (2019, p. 13). Those seeking solidarity amongst humans and nonhumans must resist this catastrophic "severing" that has alienated humans' social, psychic, and philosophical ties to the biosphere. Morton's sense of solidarity, however, does not fit in with any of the contemporary solidarity theories exemplified by what he names "explosive holism" such as the ecological resonance of the ruling class, agricultural era-religious communion, cybernetically automated governance, and fascism-all of which demarcate an essentialist human social space and believe that social space is larger than the sum of its parts (2019, p. 25). The struggle for solidarity with nonhumans needs to dismantle the logics of the teleological, hierarchical, and patriarchal ways of organizing social space and the relations of humans to nonhumans. To counter the kind of solidarity advocated by "explosive holism," Morton defines solidarity or "the symbiotic real" as "implosive holism" or a communist incorporation of nonhumans (2019, p. 27). Given the fact that humans are largely comprised of nonhumans such as bacteria, viruses, microorganisms, and so forth, the very being of humans has always been a symbiotic entity. Seen in this light, "implosive holism" demands us to rethink what really defines humans as human, which turns out to be a cluster of lives or life-forms. More than being a singular entity with a seemingly unique intelligence, mind, or consciousness, the human has always been a multitude.

It is in this sense of communist solidarity/symbiosis of humans and nonhumans that Morton argues for the significance of Marxism, which, he says, "is already haunted by the nonhuman" (2019, p. 28). Indeed, in Marxism, human economic relations are considered as the "Decider" that structures a reality in which human relations are produced and shaped by relations between commodities (2019, p. 39). Nevertheless, Morton thinks that such reduction of the human to the nonhuman also suggests a way out. These relations concern, as he puts it, "the enjoyment of life, of creativity, of "production'," and although Marxism might connote that the humans are stuck in capitalism, it also states that "capitalist relations don't exhaust humans" (2019, p. 40). Morton continues to read closely 
Marx's concept of species-being in the Economic and Philosophical Manuscripts (1844), revealing the ambiguous human-centrism in Marx's thought. On Morton's reading, Marx recognizes the universality of nonhumans' species-being that embodies "an interface between nature and nature" (2019, p. 41), while a few lines later, Marx concludes that only humans have species-being.

Morton's configuration of Marxism is provocative and yet somewhat slippery. Morton acknowledges that Marxism is anthropocentric on the one hand, while also implying an inclusion of nonhumans in its discussion of humans' species-being as one that is embedded and entangled with matter, objects, technical tools, and so on, on the other. For instance, Marx laments in Capital (1867) that capitalism produces the depletion of soil. Techniques that increase fertility of the soil in a given time turn out to be "a progress towards ruining the more long-lasting sources of that fertility" (2019, p. 62). As such, in capitalism the soil becomes the original source of wealth, and the fertility of the soil whose loss Marx laments becomes anthropocentric given that the soil in Marx's discussion is keyed to a sustainable agriculture serving humans. Thus, Morton suggests that "the implications of nonhumans means that we might be able to un-erase them within Marxism; such an action seems highly unlikely within the realm of strict capitalist economic theory" (2019, p. 62). Yet, Morton seems to engage more in conceptual play with Marx's implicit discussion of the nonhuman than with more foundational questions like the conception of nature in Marxism. In Morton's comparison between Marxism and capitalist theory, the question of nature becomes fundamental to understanding the implicit "anti-humanistic" conceptualization of nature in Marxism as well as the entrenched humanist extraction of nature in neoliberal capitalism. Morton's discussion of the nonhuman in Marxism, although highly illuminating, remains unfortunately abstract and unclear. For instance, is the inclusion of nonhumans able to reconcile the conflict between Marx's critique of the exploitative characteristics of capitalism and his anthropocentricism? Can merely the inclusion of nonhumans signal a communist solidarity of all beings? Morton has touched upon the intricacies in Marxist thought, but he fails to tease out more of Marx's configuration of the relationship between human and nature. For example, in Economic and Philosophical Manuscripts, Marx also wrote: "Nature is man'sinorganic body, that is to say, nature in so far as it is not the human body. Man lives from nature... and he must maintain a continuing dialogue with it if he is not to die. To say that man's physical and mental life is linked to nature simply means that nature is linked to itself, for man is a part of nature" (1975, p. 276). For Marx, not only is the human a part of nature, but also humans are in a constant process of encounter and confrontation with nature insofar as human beings need to rely on nature to survive. In other words, Marx's ecological thinking lies in his understanding of a dialectic humanitynature relation, which is in fact largely missing in Morton's explication of Marxism.

The novelty of Morton's philosophy in Humankind is most apparent in his nuanced elaboration of concepts such as the "spectrality" of the human, the symbiotic real, and a solidarity that moves beyond the Derridian sense of ontological justice. From the perspective of $\bigcirc \bigcirc \bigcirc$, ecological beings are spectral things (2019, p. 55). Morton astutely points out the ambiguities within the division between life and non-life, as biology has already demonstrated that the existence of the human is in fact a fuzzy, symbiotic coexistence with nonhuman entities such as viruses and microorganisms. Spectrality, as Morton writes, "will aid us in imagining something like an ecocommunism, a communism of humans and nonhumans alike" (2019, p. 55). Ecocommunism, a pervasive ecological awareness in our era, recognizes that there is a "bewildering variety of scales, temporal 
and spatial, and that the human ones are only a very narrow region of a much larger and necessarily inconsistent and varied scalar possibility space, and that the human scale is not the top scale" $(2019, \mathrm{p}$. 186). Thinking the spectral is to think a communist type of togetherness wherein multiplicity, instability, and unknowability constitute the essence of ecological beings.

In his analysis of humans' ecological being, Morton effectively fuses his already (well-) known notions of "hyperobjects" and "dark ecology" with the neologisms developed in Humankind. If the concept of hyperobjects has captured the sense of expansive scales on which ecological issues unfold, Morton further challenges humans' perception by pointing out the fact that we are as ignorant of global warming as of the microbiome inhabiting our bodies. Hyperobjects therefore invite us to think through what is unthinkable by and about the human. In this sense, spectrality adds an aesthetic dimension to the weird, uncanny, and even spooky beings of human and nonhuman hyperobjects. For OOO thinkers, "aesthetics is the root of all philosophy," as Graham Harman states (2017, p. 59). In an ecological age, Morton believes that spectrality should be appreciated alongside beauty, as beauty is neither pure nor unadulterated but is "haunted by its spectral double" (2019, p. 65). While imperceptible, undecidable, and colossal ecological scenarios to which we cannot directly point emerge as they always have, spectrality, in spite of being disgusting or shocking, turns out to be an apt word for us to articulate our ecological experience. Thus, hyperobjects, a term that originally referred to things spinning spatiotemporal scales that exceed human perception (Morton, 2013, p. 1), has become the "spectral" hallmark of all forms of entities that exist in a well-nigh ungraspable ecological condition. Spectrality therefore enables us to think beyond the human, relating humans' existence with other seemingly horrific, ghostly, and repulsive forms of beings such as spirits, monsters, and viruses.

Morton ends Humankind with a long chapter devoted to a discussion of "kindness." In defining kindness as "acknowledgment of nonhumans" (2019, p. 140), Morton endorses a sense of appreciation, fascination, and enjoyment in relation to the nonhuman. It seems that Morton's notion of kindness resonates nicely with Donna Haraway's advocation of making kin in the Chthulucene. As Haraway says, "I think that stretch and recomposition of kin are allowed by the fact that all earthlings are kin in the deepest sense" (2016, p. 103). Likewise, by kindness Morton means the kinship and friendship that inhere in the communist solidarity with nonhumans. The difference is that Haraway is concerned more about the non-genetic/non-genealogical kinship of all beings, whereas Morton highlights the aesthetic power of embracing kindness. When describing the fascination with enhancing and expanding nonhumans' pleasure, Morton writes:

In this way, vegetarianism (for example) is not about opposing cruelty or minimizing suffering or enhancing one's health by returning to a more natural way of being, but about a pleasure mode designed to maintain or enhance the pleasure modes of pigs or cows or sheep and so on...Motivations for ecological ethics and politics can no longer be trapped in theistic discourse of good and evil, or biopolitical discourses of sickness and health, or petrocultural discourses of efficiency and sustainability (2019, p. 144).

For Morton, kindness means that aesthetics and experience precede ethical, political, and religious doctrines and imperatives. Kindness refers to an acknowledgment that humans are "permeated with other beings, physically and experientially and everything else" (2019, p. 145) in the first place, thereby evoking a profound appreciation of the existential joy, pleasure, and beauty of nonhumans. 
Toward the end of the book, drawing on Christopher Nolan's film Interstellar (2014), Morton probes the basic question of how we have become disconnected from other terrestrial lifeforms. "Interstellar isn't really about leaving the Earth. It's about how to restart our ability to imagine who we are" (2019, p. 146). Blighted crops are symptoms of an ecological catastrophe that is not in the least futuristic but "a continuity between ourselves and all other agrilogistic eras" (2019, p. 147). In Interstellar, futurity re-inscribes the severed relation between humans and other beings and calls for reflection upon a worsening ecological scenario where we have already been. It is a film that poses a question about how we interpret and communicate with nonhuman beings, animals, plants, and extraterrestrial beings alike. Instead of merely imagining a future as the lives we might lead, Interstellar for Morton requires us to rethink how to tell an apocalyptic nightmare and how to account for our past and present. Crucially, in these stories of kindness and solidarity, humans must dance together with nonhumans.

Overall, to conclude, Humankind is a daring enterprise wherein Morton's exhilarating treatment of ecological issues and communism hits the nerve of the contemporary historical moment. Despite the occasionally repetitive and elusive prose of the book, Humankind exemplifies the philosophical breadth and depth of Morton's ecological thinking that has infused the field of ecocriticism since his previous works. It will likely give rise to a new series of studies and discussions of the solidarity of humans and nonhumans, aesthetically and ontologically, as well as Marxism's possible responses to planetary changes.

\section{References}

Haraway, D. J. (2016). Staying with the Trouble: Making Kin in the Chthulucene. Durham and London: Duke University Press.

Harman, G. (2017). Object-Oriented Ontology: A New Theory of Everything. London: Penguin Books.

Marx, K. (1975). Economic and Philosophical Manuscripts of 1844 in Marx and Engels Collected Works, Volume 3. New York: International Publishers.

Morton, T. (2019). Humankind: Solidarity with Nonhuman People. London and New York: Verso.

Morton, T. (2013). Hyperobjects: Philosophy and Ecology after the End of the World. Minneapolis: University of Minnesota Press. 